\title{
KOMPARASI BOBOT POTONG, BOBOT KARKAS DAN PERSENTASE KARKAS PADA SAPI RANCAH DAN PERANAKAN ONGOLE BERDASARKAN MUTASI PADA GEN LEPTIN
}

\author{
(Comparison of Slaughter Weight, Carcass Weight, And Carcass Percentage of Rancah And \\ Ongole Grade Catlle Based On Mutations In Leptin Gene) \\ Nena Hilmia ${ }^{1}$, Dedi Rahmat. ${ }^{1}$, Primiani Edianingsih ${ }^{1}$, Yurleni Faisal ${ }^{2}$ \\ ${ }^{1)}$ Produksi Ternak Fakultas Peternakan Universitas Padjadjaran \\ Jl. Raya Bandung Sumedang Km 21 Jatinangor Sumedang Jawa Barat, Indonesia \\ ${ }^{2)}$ Program Studi Peternakan, Fakultas Peternakan Universitas Jambi \\ Penulis Koresponden : nena.hilmia@unpad.ac.id
}

Article Submitted :30-12-2021

Article Accepted :26-01-2022

\begin{abstract}
Weight and percentage of carcass are very important in beef cattle production because they are an economic parameters, which describe the amount of parts that can be consumed. This study aimed to determine the effect of mutations in $\mathrm{R} 25 \mathrm{C}$ and $\mathrm{R} 25 \mathrm{H}$ in the Leptin gene on slaughter weight, carcass weight and carcass percentage of Rancah and Ongole Grade cattle. The secondary data used were 4 genotypes in Rancah cattle, namely CC, CT, CA and TT respectively, 6, 2, 4 and 2 heads and 3 genotypes in Ongole Grade cattle, namely CC, CT and CA, respectively. 4, 2 and 1 heads. The data on slaughter weight, carcass weight and carcass percentage were 14 male of Rancah cattle aged $1.5-2.5$ years, while data for PO cattle were obtained from 7 male of Ongole Grade 1.5 years old. Parameters measured were slaughter weight, carcass weight, carcass percentage. Data were analyzed descriptively. The results showed that genetic diversity in Rancah and PO cattle due to the R25C and R25H mutations in the Leptin gene was not differences in slaughter weight, carcass weight and carcass percentage.
\end{abstract}

Keywords: Mutation, Rancah Cattle, Ongole Grade Cattle, Leptin Gene, Carcass Percentage

\section{PENDAHULUAN}

Dalam rangka memenuhi kebutuhan konsumsi daging di Indonesia, salah satunya adalah memaksimalkan potensi ternak lokal, baik produktifitas maupun populasinya. ternak lokal memiliki kapasitas reproduksi yang baik pada jantan maupun betinanya, sehingga peningkatan produktivitas lebih diarahkan kepada kemampuan pertumbuhan dan efisiensi pakan. Pertumbuhan dipengaruhi oleh faktor genetik berhubungan dengan gen-gen yang dimiliki suatu bangsa, rumpun atau individu tersebut, serta pengaruh lingkungan berkaitan dengan seluruh aspek yang mempengaruhi pertumbuhan diluar genetik, termasuk pakan, lingkungan klimatologis, manajemen dan sebagainya. Kapasitas genetik suatu rumpun ternak termasuk sapi, dapat digali lebih jauh dengan berkembangnya teknologi molekuler yang dapat mendeteksi mutasi pada tingkat nukleotida yang akan mempengaruhi ekspresi gen dalam menghasilkan protein. Teknologi ini mampu mengeksplor gen-gen potensial yang mempengaruhi fenotipe, sehingga bisa dijadikan marka gen untuk seleksi.

Gen leptin adalah salah satu kandidat gen yang berkontribusi terhadap pertumbuhan, karena berperan dalam 
regulasi metabolisme energy dan asupan makanan (feed intake) yang akan mempengaruhi pertumbuhan. Penelitian tentang gen leptin pada sapi mengkonfirmasi bahwa mutasi pada gen ini berkorelasi dengan produktifitas yaitu regulasi asupan makanan, masa tulang neuroendocrine, pembentukan tulang, distribusi lemak, metabolisme lemak dan imunitas di dalam tubuh (Cirmanova et al. 2008; Upadhyay et al. 2015; Sainz, et al. 2017)

Eksplorasi mutasi gen Leptin pada beberapa bangsa sapi pedaging menunjukkan adanya asosiasi antara polimorphisme karena adanya mutasi pada gen tersebut dengan sifat-sifat produksi. Hasil penelitian De Vuyst (2010) mengemukakan mutasi Cytosin (C) menjadi Timin ( $\mathrm{T}$ ) pada gen leptin exon 2 yang berdampak pada pengkodean asam amino Arginina menjadi Sitosina, mutase ini lebih bernilai ekonomis karena menghasilkan kualitas karkas yang lebih baik. Selanjutnya hasil penelitian Woronuk et al., (2012) mengkonfirmasi adanya asosiasi yang signifikan mutasi pada gen leptin di posisi sekuen nukleotide C1047T/ Arg25Cys/R25C dengan bobot badan dan tebal lemak punggung.

Sapi Rancah dan PO adalah sapi lokal yang cukup potensial sebagai sumber penyedia daging untuk kebutuhan konsumsi, khususnya di Jawa Barat, karena kedua rumpun sapi ini dominan dipelihara oleh peternak di daerah ini. Informasi potensi genetik yang dieksplor dengan teknologi molekuler pada kedua rumpun sapi tersebut masih terbatas. Berdasarkan informasi diatas penelitian ini bertujuan untuk mengetahui pengaruh mutasi pada gen leptin yang disebabkan SNP R25C dan R25H dengan bobot potong, bobot karkas dan persentase karkas pada sapi Rancah dan PO.

\section{METODE PENELITIAN}

\section{Materi Penelitian}

Data mutasi R25C dan R25H pada gen leptin sapi Rancah dan PO diperoleh dari penelitian Hilmia (2013), yaitu terdapat 4 genotipe pada sapi Rancah, yaitu CC, CT, CA dan TT masing-masing sebanyak, 6, 2, 4 dan 2 ekor serta 3 genotipe pada sapi PO, yaitu $\mathrm{CC}, \mathrm{CT}$ dan $\mathrm{CA}$, masing-masing sebanyak 4, 2 dan 1 ekor. Data bobot potong, bobot karkas dan persentase karkas, sebanyak 14 data sapi Rancah jantan umur 1.5 - 2.5 tahun, sedangkan data sapi PO diperoleh dari 7 ekor sapi PO jantan umur 1,5 tahun.

\section{Parameter yang diukur}

1. Bobot potong adalah hasil penimbangan sapi sebelum dipotong

2. Bobot karkas panas adalah hasil penimbangan karkas setelah pemotongan.

3. Persentase karkas adalah perhitungan berdasarkan perbandingan bobot karkas panas dengan bobot potong dikalikan $100 \%$

\section{Analisis data}

Data yang bobot potong, bobot karkas dan persentase karkas dianalisis secara deskriptif

\section{HASIL DAN PEMBAHASAN}

Produktifitas sapi potong salah satunya dinilai dari bobot potong, bobot karkas dan persentase karkas, karena komponen ini dapat menjadi bahan evaluasi pada pemeliharaan sapi pedaging agar menguntungkan. Pengaruh keragaman genetic yang disebabkan adanya mutasi pada gen-gen yang berkontribusi pada pertumbuhan dapat dievaluasi dari ketiga parameter diatas. Rataan bobot potong, bobot karkas dan persentase karkas berdasarkan genotipe gen Leptin pada sapi Rancah dan PO disajikan pada Tabel 1. 
Tabel 1. Rataan bobot potong, bobot karkas dan persentase karkas berdasarkan genotipe gen Leptin pada sapi Rancah dan PO

\begin{tabular}{|c|c|c|c|c|c|}
\hline \multirow{2}{*}{ Parameter } & \multicolumn{5}{|c|}{ Genotipe } \\
\hline & & $\mathrm{CC}$ & $\mathrm{CT}$ & $\mathrm{CA}$ & TT \\
\hline Sapi Rancah & $\mathrm{n}$ & $\mathrm{n}=6$ & $\mathrm{n}=2$ & $\mathrm{n}=4$ & $\mathrm{n}=2$ \\
\hline Bobot potong $(\mathrm{kg})$ & 14 & $205,83 \pm 21,3$ & $205,50 \pm 40,3$ & $216,00 \pm 26,3$ & $181,50 \pm 3,5$ \\
\hline Bobot karkas (kg) & 14 & $105,67 \pm 12,5$ & $106,00 \pm 19,8$ & $110,75 \pm 16,5$ & $97,00 \pm 5,7$ \\
\hline Persentase Karkas (\%) & 14 & $51,33 \pm 2,03$ & $51,65 \pm 0,47$ & $51,21 \pm 1,6$ & $53,42 \pm 2,08$ \\
\hline Sapi PO & & $\mathrm{n}=5$ & $\mathrm{n}=1$ & $\mathrm{n}=1$ & . \\
\hline Bobot potong $(\mathrm{kg})$ & 7 & $287,00 \pm 16,9$ & 271,00 & 303,00 & \\
\hline Bobot karkas (kg) & 7 & $146,40 \pm 13,5$ & 148,50 & 161,00 & \\
\hline Persentase Karkas (\%) & 7 & $50,95 \pm 2,28$ & 54,80 & 53,14 & \\
\hline
\end{tabular}

Hasil penelitian menunjukkan rataan bobot potong sapi Rancah berdasarkan genotipe berkisar antara $181,50 \mathrm{~kg}-$ 216,00 kg, sedangkan pada sapi PO berkisar antara $271 \mathrm{~kg}$ - $303 \mathrm{~kg}$. Bobot potong sapi Rancah yang merupakan cikal bakal sapi Pasundan, pada penelitian ini relative lebih rendah dari standar bobot badan sapi Pasundan Jantan sebesar 240,4 $\pm 34 \mathrm{~kg}$ (Kepmentan, 2014). Demikian halnya bobot potong sapi PO pada penelitian ini, relative lebih rendah dari hasil penelitian Carvalo, dkk (2010) yang mengemukakan rataan bobot badan awal pemeliharaan enam sapi PO adalah $315.6 \pm 39.46 \mathrm{~kg}$ demikian halnya dengan hasil penelitian Purbowati et al. (2015) yang memperoleh bobot potong sapi PO sebesar 474,5 kg. Bobot karkas pada penelitian ini baik pada sapi Rancah maupun PO relatif lebih rendah dari penelitian lainnya, sejalan dengan bobot potong yang relative lebih rendah dari penelitian sebelumnya. Penelitian Purbowati, dkk. (2015) menyatakan bobot karkas sapi PO di RPH Semarang mencapai 236,25 kg. Perbedaan bobot potong dan bobot karkas dapat disebabkan bangsa dan umur pemotongan, hal ini sejalan dengan hasil penelitian Setiyono, dkk. (2017) yang mengemukakan bahwa bangsa sapi (PO, Simpo,Limpo) dan umur pemotongan $(0-4$ tahun) berpengaruh secara signifikan pada bobot potong dan bobot karkas.
Persentase karkas pada penelitian ini baik pada sapi Rancah, maupun sapi PO diatas $50 \%$. Hasil penelitian ini relatif lebih besar dari hasil penelitian Calvalho et al. (2010) yang menunjukkan persentase karkas sapi PO sebesar 49,4\% serta penelitian Purbowati, dkk. (2015) yang memperoleh persentase karkas sebesar 49,76\%. Hasil penelitian Marino, dkk (2020) yang dilakukan pada sapi lokal di Menado, memperoleh persentase karkas dengan kisaran 47,14\% - 54,46\%. Selanjutnya Purbowati, dkk. (2015) mengemukakan bahwa persentase karkas dipengaruhi umur, bobot potong, bobot karkas dan pakan yang dikonsumsi sebelum dipotong.

Hasil penelitian persentase karkas sapi Rancah pada genotipe yang berbeda berdasarkan mutasi pada gen Leptin berkisar antara $51.21 \%$ - $53.42 \%$ dan pada sapi PO $50,95 \%-54,48 \%$. Hasil ini menunjukkan nilai yang relatif sama atau tidak terdapat perbedaan persentase karkas diantara genotipe. Beberapa hasil penelitian polimorphisme gen Leptin yang dihubungkan dengan karkas, umumnya berkaitan dengan nilai karkas secara keseluruhan, deposisi lemak dan kualitas lemak karkas. Hasil penelitian Nkrumah et al. (2004) mengemukakan persentase karkas sapi bergenotipe CC CT dan TT, tidak berbeda masing-masing sebesar $63.7 \%$, $63.8 \%$ dan $64 \%$, namun perbedaan genotipe Leptin berpengaruh terhadap kualitas lemak 
karkas (fat grade), nilai karkas (yield grade) dan produksi daging tak berlemak (lean meat yield). Alel homozigot thymin (TT) memiliki kualitas lemak karkas yang lebih baik, dibandingkan gen heterozigot dan homozigot cytosin (CT dan CC) dan CT lebih baik dari CC. Genotipe TT menghasilkan produksi daging tak berlemak dan produksi karkas lebih rendah dari genotipe CT dan CC. Berat karkas genotipe CC lebih tinggi dari TT, dan tidak berbeda antara CT dan TT. Buchanan et al. (2002) mengidentifikasi SNP pada 154 sapi pejantan menunjukkan alel $\mathrm{T}$ berkaitan dengan peningkatan deposisi lemak dan tingginya ekspresi leptin mRNA pada jaringan lemak. Alel T berhubungan dengan karkas yang lebih berlemak.

Berdasarkan hasil penelitian diatas, adanya mutasi gen leptin pada posisi R25C dan $\mathrm{R} 25 \mathrm{H}$ tidak memberikan pengaruh yang berbeda pada bobot potong, bobot karkas maupun persentase karkas pada sapi Rancah maupun PO. Hal ini disebabkan ketiga parameter diatas merupakan hasil pertumbuhan yang tergolong kepada sifat kuantitatif, dimana sifat ini dipengaruhi banyak pasangan gen. Pertumbuhan diregulasi oleh banyak gen tidak hanya leptin, seperti yang dikemukakan Martinez dan Saladana (2012), bahwa pertumbuhan dipengaruhi banyak gen, diantaranya famili gen GH dan IGF. Selain itu sampel yang digunakan pada setiap genotipe terbatas, sehingga tidak bisa dilakukan analisis lebih lanjut.

\section{KESIMPULAN}

Keragaman genetic pada sapi Rancah dan PO karena adanya mutasi R25C dan R25H pada gen Leptin, menghasilkan bobot potong, bobot karkas dan persentase karkas yang relative sama.

\section{DAFTAR PUSTAKA}

Aberle DE, Forrest JC, Gerrard DE, Milles EW. 2001. Principles of Meat
Science. $4^{\text {th }}$ edition San Francisco (US). W.H. Freeman and Company.

Buchanan FC, Fitzsimmons CJ, Van Kessel AG, Thue TD.Winkelman_Sim DC, and Schmutz SM. 2002. Association of a missense mutation in the bovine leptin gene with carcass fat content and leptin mRNA levels. Genet Sel Evol. 34:105-116. doi: 10.1051/gse:2001006.

Carvalho MC., Suparno, dan Ngadiyono N. 2010. Pertumbuhan dan produksi karkas sapi Peranakan Ongole dan Simental_Peranakan Ongol jantan yang dipelihara secara feedlot. Bul Pet. 34(1):38-46.

Cirmanová V., M. Bayer, L. Stárka, K. Zajičková. 2008. The Effect of Leptin on Bone - An Evolving Concept of Action. Physiol res. 57 (suppl 1): S143-S151. DOI: 10.33549/physiolres.931499

DeVuyst EA. 2010. The Economics of Gene Testing Cattle. Oklahoma Cooperative Extension Service. [Internet]. Diunduh 2011 Nov 8. Tersedia pada: http://osufacts.okstate.edu.

Hilmia, N. (2013). Karakterisasi Fenotipe dan Potensi Genetik Serta Hubungannya Dengan Produktivitas Dan Kualitas Daging Sapi Lokal Di Ciamis Jawa Barat. (Disertasi). Institut Pertanian Bogor. Indonesia.

Kepmentan, R.I. No.1051/Kpts/SR.120/ 10/2014. (2014). Penetapan Rumpun Sapi Pasundan.

Marino AM, Lomboan A, Pudjihastuti E, dan Sondakh EHB. 2020. Berat potong, berat karkas dan persentase karkas sapi potong lokal yang dipotong di rumah potong hewan Menado. Zootec Vol 40. N0. 1: 191-195 
Martinez JAA and Saldana HAB. 2012. Genetic Engineering and Biotechnology of Growth Hormones. In Genetic Engineering - Basics, New Applications and Responsibilities. Saldaña nHAB (Ed.). In-Tech (Croatia).p. 173-196. DOI: 10.5772/38978. Available : http://www.intechopen.com/books/

Nkrumah JD, Li C, Basarab JB, Guercio S, Meng Y, Murdoch B, Hansen C, and Moore SS. 2004. Association of a single nucleotide polymorphism in the bovine leptin gene with feed intake, feed efficiency, growth, feeding behaviour, carcass quality and body composition. Can J Anim. Sci. 84: 211-219.

Purbowati E, Lestari CMS, Sarie NA, Haryati Y, Saputra MW, Saputro WS, Istiadi M, Arifin M, Rianto E, Purnomoadi A. 2015. Karakteristik Sapi yang Dipotong di Rumah Pemotongan Hewan Kota Semarang . Prosiding Seminar Nasional Teknologi Peternakan dan veteriner: Hal 42-47

Sáinz, N, J. Barrenetxe, M.J. MorenoAliaga, \& Martínez, J. A. (2015).
Leptin resistance and diet-induced obesity: central and peripheral actions of leptin. J. Metab. Clin and exp, 64, $35-46$.

Sutiyono, Andri, HAK. dan Rusman. 2017. Pengaruh bangsa umur dan jenis kelamin terhadap kualitas daging sapi potong di daerah Istimewa Yogyakarta. Buletin Peternakan Vol. 41(2); 176-186.

Tonbesi, TT, Ngadiyono N dan Sumadi. 2009. Estimasi potensi dan kinerja sapi bali di Kabupaten Timor Tengah Utara, propinsi Nusa Tenggara Timur. Bul Petern. 33(1): 30-39.

Upadhyay, J., Olivia, M.F., \& Cristos, M. (2015). The role of leptin in regulating bone Metabolism, 64 (1):105-13. http//doi: 10.1016/j.metabol.2014.10.021.

Woronuk G.N, Marquess F.L. James S.T, Palmer J, Berryere T, Deobald H., Howie S. \& Kononoff P.J. (2012). Association of leptin genotypes with beef cattle characteristics. [Short Communication]. Anim. Genet, 1-3. 